\title{
sciendo
}

\section{Politics and Eschatology in Iran}

\author{
Anna Maria Cossiga ${ }^{1}$, Alessandro Figus ${ }^{2}$ \\ ${ }^{1}$ Senior analyst - European Foundation for Democracy - email: am.cossiga@gmail.com \\ ${ }^{2} \mathrm{PhD}$ - International Institute of Management IMI-Nova (Moldova) \\ email: vicerector.int.iminova@gmail.com
}

Doi: $10.2478 /$ gssfj-2021-0006

\begin{abstract}
The article studies the Iranian political society, starting from the analysis of the Iranian Constitution, the only one in the world characterized by "eschatological" components. The authors retrace the bistory of the birth of the Islamic Republic of Iran, which is fundamental to ensure an interpretation of the politics of that country that takes into account religious and cultural factors and clarifies possible future developments. Furthermore, they address the problem relative to the symbolic system on which the configuration of the Iranian Republic theoretically rests, which must necessarily come to terms with pragmatic reality. In fact, to have a following in his revolutionary project, Khomeini used the "symbolic spring", in which the politics of Iran in these years have demonstrated the necessity of realism with a parallel with the concept of agnosticism, which thus becomes natural, in opposition to theories that are often more subjective than objective. Finally, the authors go so far as to say that today is the time for a change, even if in a country like Iran, everything proceeds slowly. Young Iranians will have to obtain a role, reorganize and rekindle from below. The involvement of the young people themselves can increase hope in a process that promises to be complex and articulated, which sees the theocratic model as opposed to the model of Muslim politics in a purely eschatological context, which to most, especially in the West, appears anachronistic, but this is not always the case.
\end{abstract}

Keywords: Iran, eschatology, Islamic republicanism, Islam.

\section{The Middle East Chaos}

How, in the Middle East chaos, can Iran cooperate with the "Great Satan"? This is how Ayatollah Khomeini defined the United States, and that appellative has come to be, in the Iranian imagination, but also in ours, synonymous with the "Enemy" of the Islamic Republic: the West. In our highly secularized world, religious symbols understood as representations of shared meaning that shape the way we understand and evaluate the world, seems to have lost all political significance $^{28}$. But this is certainly not the case in Iran, where, in the words of Khomeini himself, "religion and politics are two coincidental phenomena since both

${ }^{28}$ Although, to be fair, Bush Jr.'s vision of a fight against the Axis of Evil, which included Iran, did not differ, symbolically, from Khomeini's. 
offer the instruments to guide and administer a society towards the well-being and good of man"29. Starting from an analysis of the Iranian Constitution, in effect, this is "the only one in the world characterized by eschatological components" ${ }^{30}$ and retracing the history of the birth of the Islamic Republic, we would like to propose an interpretation of the politics of that country that takes into account religious and cultural factors.

The "fundamentalist" nature of the Iranian state has been noted by numerous authors ${ }^{31}$ who, in their comparative study of fundamentalist movements present today within various religious systems, have highlighted certain common characteristics: they arise in traditionalist contexts and react both to the marginalization of religion from political life, and to modernization (not modernity), as well as to the stresses due to the comparison with other models of thought; they have essentially political objectives and want to remedy what they consider a "distortion of history", orienting society again in accordance with a religious ideology; they rely on sources considered infallible and impossible to historicize, which may be sacred texts, schools of jurisprudence or institutions; they follow a charismatic leader; they configure the existence of an Enemy, which may be external (other faiths, secularists, the West) or internal (secular co-religionists or those of other orientations); they reject modernity in an ambivalent way, condemning its secular and pluralist ideological premises, but exploiting its instrumental benefits. ${ }^{32}$ Analyzing Islamism more specifically, Renzo Guolo points out that "although it is the bearer of a political theology centered on the West as the figure of the Enemy, it is equally true that the clash is also between Islam and Islam, between a religious tradition and an ideological interpretation of religion" ${ }^{33}$. Moreover, and contrary to what is often believed, "Islamism, even if it invokes a return to the 'faith of the ancients' is a modern movement ... It 'reinvents tradition' by subjecting the very religious status of Islam to disruptive tensions and denying its historical developments in the name of an 'obsession with authenticity"34.

In the case of the Iranian Republic, the presence of many of the characteristics noted by scholars is clear. It was born, first of all, as a reaction to the marginalization of religion in the political field and its creation derives from the victorious struggle against an external enemy, secular and pluralistic, the United States; and an internal enemy, symbolized by the Shah, who has distanced himself from the "true faith", wants to modernize the country and is an ally of the infidels. Analyzing the nature of the State, we note that it has a constitutional form, as in the democracies known

29 Pejman Abdolmohammadi, "The Islamic Republicanism of Ayatollah Khomeini," Modern East, New Series, Year 89, No. 1 (2009), p.89.

${ }^{30}$ A. Figus, Iran's foreign policy between the West and the nuclear crisis, Eurilink, Rome 2014.

31 On the question of religious fundamentalism and the debate on the use of the term "fundamentalism", see, among others, L. Ozzano, Fondamentalismo e democrazia, Il Mulino, Bologna 2009 and R. Guolo, Il fondamentalismo islamico, Laterza, Bari, 2002.

32 See R. Ozzano, op. cit. , pp. 57-8.

${ }^{33}$ R. Guolo, The Islamic Fundamentalism op. cit. , p V. The emphasis is ours.

34 Ibid, p. VI 
to us, and provides for a parliament, the Majlis, a president of the republic, and institutional bodies, all elected by the people. But, although it assumes a "modern" configuration, its government is conducted on an exclusively religious basis; and Khomeini, in his Islamic Government, explains this clearly:

"First of all, it is not possible to judge the politics of a state like the Islamic Republic of Iran using the 'parameters' of the parliamentary democracies of the West. The Islamic government is not akin to current systems of government. (...) The Islamic government is not despotic, but constitutional. However, it is not constitutional in the current meaning of the word, which refers to the parliamentary system or the people's councils. It is constitutional in the sense that those who are in charge of public affairs observe several conditions and norms emphasized in the Qur'an and Sunna, in which the necessity of observing the Islamic system and applying the dictates and laws of Islam is expressed. That is why the Islamic government is the government of the Divine Law." 35

As for the ideological issue, one of the characteristics of fundamentalisms already mentioned is the same Preamble of the Iranian Constitution that underlines its importance:

"The essential characteristic of this Revolution, in comparison with other movements that have occurred in Iran during the last century, lies in its ideological and Islamic character. The Muslim nation of Iran, after the experience of the anti-dictatorial Constitutional Movement and the anticolonialist Oil Nationalization Movement, learned the valuable lesson that the fundamental and obvious reason for the failure of these movements was the absence of an ideological component. ${ }^{36 "}$.

\section{Iran: the ideological base}

The ideological base of the Iranian Republic derives, mainly, from the thought of Rohanan Komeini, certainly a charismatic and "revolutionary" leader compared to the Shiite tradition. His political ideas, matured since his youth and then developed and modified during the long years of exile in Iraq, Turkey, and France, are the basis of the structure and the government of the Iranian Islamic state. As Enzo Guolo points out, "the Islamic revolution takes place in a context in which at the center of the mobilization 'for the rights of God' ... there is a clergy, or at least a part of it, which has become a combatant. It is, however, a 'revolution against tradition' and not a traditionalist revolution". ${ }^{37}$ The "revolutionary" Khomeini, as a good "fundamentalist", while referring to the Shiite tradition, distorts it to his own advantage and "invents" the theory of velayat-e-faqhi, the government of the jurist, which finds expression in Article 5 of the Iranian Constitution:

\footnotetext{
${ }^{35}$ Ruhollah Khomeyni, The Islamic Government, LedE, Rome 1980, p.69.

36 The text of the Iranian Constitution is taken from A. Figus, Foreign Policy etc., op. cit.

${ }^{37}$ R. Guolo, Il fondamentalismo (Fundamentalism), op. cit., p. 59. The emphasis is ours.
} 
During the Occultation of Harrate-e Valli-e Asr ${ }^{38}$ (may God hasten its appearance), the nation of the Islamic Republic of Iran will be led by a Faqih who is righteous, virtuous, well versed in today's world, courageous and who is an efficient administrator.

Hazrate-e Valli-e Asr is the last Imam of duodeciman or Imamite Shiite Islam, Muhammad

al- Mahdi ("the awaited" or "the well-guided"), who is said to have gone "into concealment" in 874. According to Shia belief, he remains present in the present world not "in spirit, but alive and well, only hidden, miraculously long-lived, and will return to appear, never having died, at the end of time. The occult Imam is called 'the Imam of Time' or 'the Lord of the present age,' and the Muslim community and the world could not subsist without an ever-living and active Imam." ${ }^{39}$

A key to interpreting the Iranian revolution and the eschatological dimension of its politics can be derived from the historical-religious and anthropological analyses of Ernesto De Martino. One of the most important hermeneutical tools developed by the Neapolitan scholar is the thesis of the "crisis of presence as a risk of not being in the world and the discovery of an order of techniques (to which religion belongs) intended to protect presence from the risk of losing the categories with which it rises on the blind vitality and ingens sylva of nature, and also intended to redisclose mediately the world of values compromised by the crisis." 40

The danger of the dissolution of presence exists not only for the individual but for the entire society and the way to neutralize this risk is to employ what De Martino calls the "mythical-ritual symbol", through which history is ritually interrupted and we return to the "time of myth". Myth is the meta-historical horizon that "ritual repeats and renews, reabsorbing in them the historical proliferation of worldly becoming and re-presenting the world (in our case, the Islamic world) again and again according to the exemplary power of the first time, when that world began by the inaugural decision of the gods: so that maintaining the world, sustaining life, means ritually repeating its founding myth. (...) The myth is a myth of the center, of a privileged event that gives meaning to the totality of holy history, both in the sense of the past and of the future: so that event, history enters the perspective of ending, and nothing decisive can happen anymore, except the end and the continuous sacramental iteration of the central event that has decided once and for all" ${ }^{41}$.

The mythical-ritual symbols are therefore socializing symbols that allow the individual and societies to face the historical becoming leaning on tradition.

Applying this analysis to the Iranian case, the "crisis of presence" of Islamic society is determined by the Shah's modernization and the presence of Western (American)

38 Hazrate-e Valli-e Asr, the Mahdi, the Hidden Imam. See below for an in-depth discussion of the doctrine. 12 A. Bausani, L'Islam, Garzanti, Milan 1987, p. 104.

39 A. Bausani, L'Islam, Garzanti, Milan 1987, p. 104.

${ }^{40}$ E. De Martino, The Magical World. Prolegomeni a una storia del magismo (1948), Boringhieri, Turin 1997, pp. 273-274, concluding postilla of the second edition.

${ }^{41}$ E. De Martino, La fine del mondo. Contributo alle analisi delle apocalissi culturali (1977), Einaudi, Torino 2002, p. 240. 
infidels. The solution lies in a return to the "mythical past" in which Islam was founded and in which the norms governing that particular society were established. The eschatological horizon, the waiting for the Mahdi, is also part of this type of "solution technique". Applying to the Iranian revolution the words that De Martino uses to describe the Christian apocalyptic, "in the eschatological dimension that lies beyond the human world, the perspective of redemption takes shape. (...) [In the case in which the eschaton is assumed as a sure reality, although remote and unspecifiable] the human work (...) acquires its full depth" ${ }^{12}$ about the project of spreading the Iranian model all over the world. ${ }^{43}$

\section{The Khomeinist idea}

The Khomeinist idea of "exporting" the revolution has had alternating phases ${ }^{44}$, but, from the political point of view, once the revolution had been carried out, one question remained: what happens to the community while waiting for the Mahdi to reappear? A question to which a unanimous answer had never been given, but to which Ayatollah Khomeini responded, in an innovative way, by conceiving an Islamic republicanism in the form of a representative theocracy that made secular and religious principles coexist ${ }^{45}$. The "time of the myth" in some way "revised and corrected", in short. The Islamic government is the lens through which the Ayatollah critically observes reality, the touchstone through which all human societies are judged. The perfect government, according to Khomeini, will take shape under the name of the "Islamic Republic," a model that is completely new both in the Islamic world and in the world's constitutional panorama. ${ }^{46}$ Based on his theory of velayat-

42 Ibid., p. XI.

${ }^{43}$ In the Demartinian text, the project is to spread the word of Christ. Transferring the concept to the Iranian reality, we mean to refer to Khomeini's "permanent revolution." It is interesting to note that the idea of permanent revolution, in this case communist, goes back to Trosky.

${ }^{44}$ By the way, see Walter Posh's article "Iran. A regime caught between authoritarianism and orthodox Islamism," April 5, 2007, at www.affarinternazionali.it/articolo.asp?ID=504. The author argues that "dialoguing with the West" should not be confused with "submitting to Western hegemony." Over the past twenty years, the shifting revolutionary ideologies have crystallized into four main currents: the Islamic left, the moderate/modern right, traditional conservatives, and neoconservatives. The Islamic left is that of the revolutionary subversives that Khamenei and Rafsanjani managed to isolate in the early 1980s.

These two leaders remained for about a decade on the margins of the political arena and made a triumphant comeback under Katami in 1997, when the visionary ideology of permanent revolution and centralized economy was replaced by the more concrete project of reconciliation of political Islam with democracy. Those who, instead, had not renounced their revolutionary dreams remained in the shadows even throughout the following decade, and returned to power only in 2005 in the wake of Ahmadinejad". It seems to us that with Rohani "the visionary ideology of permanent revolution" has once again returned to the shadows.

${ }^{45}$ On the theory of velayat-e-faqhi, see especially Pejman Abdolmohammadi, "The Islamic Republicanism of Ayatollah Khomeini," Modern East, New Series, Year 89, No. 1 (2009), pp. 87 100.

46 Ibid, p. 87. 
e-faqhi, the government of the jurist, the Ayatollah argues that the right to govern was granted by God to the prophets. Since Muhammad is the last one, the Seal of the Prophets, he transmitted the guidance to the first Imam, Ali ${ }^{47}$. This guidance, temporal and spiritual, is called velayat, which after the death of the prophets becomes the exclusive right of the 12 Imams. Basing himself on the idea already expressed by some Shiite thinkers of the $\mathrm{X}$ century, Khomeini sustains that the velayat, during the Mahdi's occultation, must be entrusted to a legitimate vicar with perfect knowledge of the shari'a, sense of justice and ability to interpret Islam: the faqhi, or jurisconsult.

"Now, in the period of the Imam's absence, there are no provisions for a certain person to administer the affairs of the state. Then what is to be thought? Are we to persuade ourselves to turn away from Islam or are we to say that it came to govern people for a couple of centuries and then neglect them? ... Isn't a government one of the necessities of life? Despite the lack of a provision designating an individual to act in the name of the Imam during the period of his absence, the presence of the characteristics of the religious ruler in any individual still empowers him to govern the people. These characteristics, i.e. knowledge of Islamic law) and justice is, nowadays, present among most of our experts in jurisprudence. If they want it will be easy for them to create and establish a just government, which knows no equal anywhere in the world."148

Khomeini thus puts an end to the quietist tradition of Shi'ism, theorizing a fighting clergy engaged in the forefront of the political struggle, and does away with the idea of a Shi'a conceived as a community in waiting. He incites the faithful to rebel against the tyranny of the time and to establish a just government.

This theory, however, expressed in The Islamic Government during Khomeini's exile in Iraq, was harshly criticized by the great Ayatollahs of his time, who considered it contrary to the tradition of Shiite Islam, so much so that Khomeini, during his exile in Paris, in his interviews with the international media and in his speeches to Iranian students living abroad, completely erased the expression velayate-faqhi from his political lexicon. Even after returning to Iran and the first postrevolutionary months, he does not explicitly mention the theory. He even affirms in various interviews that, once victory is achieved, he and the other ulama will not take part in the government, but will be the spiritual and ethical guide of the governments, intervening only in case one of the secular rulers betrays the revolution, Islam. ${ }^{49}$ In the first two drafts of the Constitution, no allusion to the government of the jurist appears. Only in the summer of 1979 did Khomeini invite political activists, intellectuals, and revolutionary ulama to submit proposals. The Shiite clergy fully enters the political scene. Criticism from secular representatives

\footnotetext{
${ }^{47}$ S. Saffari "The Legitimation of the Clergy's Rights to Rule in the Iranian Constitution of 1979", British Journal of Middle Eastern Studies, Vol. 20, no. 1 (1993), p. 65.

48 P. Abdolmohammadi, "Islamic Republicanism etc.," op. cit. p. 93, note 19, R. Khomeini, Hokumat-e-Eslami (The Islamic Government), Rome 1983, p. 170.

${ }^{49}$ P. Abdolmohammadi, "Islamic Republicanism etc," op. ci., p. 96.
} 
and part of the clergy leads the Ayatollah to establish a constituent assembly elected by the people to rework the draft Constitution. The religious scientists obtain a majority and, after two years of silence, Khomeini resumes the discourse and strongly supports the inclusion of the figure of the jurisconsult in the Iranian institutional structure. For about three months after the approval of the Constitution, Khomeini holds public speeches dedicated to the explanation and legitimization of the principle. Velayat-e- faqhi, he argues, is not a concept created by the Constituent Assembly, but ordained directly by God. Those who believe that it does not exist in Islam do not know this religion well, because this foundation has existed since the origins of Islam. Some (the secularists) believe that if the figure of the Faqhi were only formal, it would be acceptable. But these people do not realize that they oppose the Islamic State and that this opposition indicates their belonging to the infidels and is a grave $\sin .^{50}$ All this sounds contrary to the statements made in Paris and requires a public explanation. In 1982, when by then power was in the hands of the Shiite clergy and Khomeini was the Supreme Leader of Iran, the Ayatollah explained the reasons for his change of heart about the role of religious scientists in politics:

"At the beginning of the revolutionary movement, during interviews with the international press, in Najaf and Paris, I believed that the task of religious scientists should be higher than dealing with executive (government) matters and that once Islam achieved victory, the clergy would continue its (religious) work. However, when we entered the country's political scene, I noticed that in case I sent all the religious scientists to only preach in the mosques, Iran would fall into the hands of the Americans or the Soviets. We experienced that the secular political figures, although some of them with religious imprint, did not share our political direction which was based on the country's selfsufficiency and complete independence from the West. And so, since we saw that it was practically impossible to find secular personalities who worthily represented the population, we were obliged to appoint a member belonging to the clergy as President of the Republic. Even now, if we found people from outside the clergy who wanted to govern the country according to God's rules, the President of the Republic, Khamenei, and his entire entourage of religious scientists would leave politics and return to religious life. ${ }^{\prime 51}$

Khomeini's innovative revolution takes place, therefore, in complete contrast with the Shiite tradition, whose symbols he reinvents and updates. Also, the eschatological component, contained in the already mentioned Article 5 of the Constitution, takes on a new meaning. Although the final "complete" redemption will take place only at the end of time, when the Mahdi will return to establish once again Islam and justice, Khomeini has ensured that human action, albeit in a perspective that also remains eschatological, assumes fundamental importance and that thanks to that action, under the guidance of the jurist and in a State such as Iran, Islam, and justice can triumph here and now, in the present time, which

\footnotetext{
${ }^{50}$ Ibid, p. 98.

51 Ibid, p. 100.
} 
becomes in a sense, the concretization of the sacred time. In the words of Fr. Abdolmohammadi, the now-implemented theory of velayat-e-faqhi "is the first Shi'ite political theory that, after the Imamate of Ali, results in an effective form of government that attempts to revive the utopian city that Shi'ism ... had lost. ${ }^{152}$

We must admit, however, that the symbolic system on which the configuration of the Iranian Republic theoretically rests must reckon with pragmatic reality. To have a following in his revolutionary project, Khomeini used the "symbolic spring," but for Iran to be able to and continue to exist in an "objective" international reality, his successors cannot but be pragmatic. Eschatology or not, the government of Islam or not, Iran's politics in recent years have demonstrated the need for realism.

The parallel with the concept of agnosticism thus becomes natural, in contrast to theories that are often more subjective than objective. The agnostic affirms that he or she does not know the answer, often affirming that an answer is not humanly identifiable, or rather that there is no answer. Specifically, this position is usually taken concerning the problem of knowledge of God or Allah, if you will, however of the Supreme. In entirely complementary and obsolete forms, it can also refer primarily to ethics, but also to politics, to society.

Thus we fall into what the Catholic la Chiesacalls the evil of intelligence, that is, agnosticism, where the transcendent can also exist but is difficult to identify and place. It becomes necessary, in this case, to use the recipe of pragmatism, to rethink the realism of knowledge because there cannot always be opposition evil-good, Christian-Muslim, we must go beyond and overcome ideological barriers, keeping in mind that the Catholic Church, which interests us much more closely, looks at the object of the agnostic philosophical position where there are primary references to the capacity of human reason to arrive at the truth of things, without stopping at their appearance, and primarily the philosophical doctrine about the natural knowledge of God.

If we look to Iran, we must therefore overcome all those theological positions which, radicalizing the transcendence of God and the weakness of human reason, declare that it is possible to know about God only those truths which come from Revelation, that is, from Sacred Scripture and Tradition, concepts which often appear more theoretical than practical.

\section{Conclusion}

Even in Iran, suddenly it was necessary to come to terms with a population exhausted by theory, by ideological slogans; also in Iran, it was imperative to return to reality and interrupt an international game often played on eschatological foundations, unique in this sense and often confronted also with forms of widespread atheism, where an agnostic does not believe that people can know if there is the existence of a God or other divinities, while an atheist says that there is no reason to believe in one or the other or that there is proof that God does not

\footnotetext{
52 Ibid.
} 
exist; on this runs the contrast with the Soviet system, both at the time of the Cold War and today referring to its transformation. It does not change the approach to religion. Thus we observe the complexity of the system now that religious atheism, agnosticism, and skepticism are increasing exponentially on a global scale. Such reflections help us to understand the authentic meaning of Muslim immigrants' demands for visibility in Europe as a whole, where society remains impregnated and influenced by secular enlightenment, which tends to conceive every faith as an irrational expression capable of nourishing a secularized state.

The project choice of where to become the root from which everything starts and to which everything arrives, the strategic center of the complex method in which agnostics and non, Muslims and Catholics, but also atheists, act; the area in which, as Edgar Morin would say ${ }^{53}$, everything meets, is strengthened and relaunched. In the mediation of power relationships and widespread interests and in the liberation of the human project, of which the religious aspect is a part, the political vision of oneself, of every entity and of reality is concentrated and this becomes the point around which everything is articulated, in the infinity of holistic integration, facing religious problems not individually, but as parts of a whole, in the same way, as happens in the biological study of a living organism. The political choice of each person becomes in this way the way out to answer the political-religious complexity of the human project that should assert itself independent from any political force and declare to have as its purpose the achievement of the effective secularity of the State.

The diffusion of atheist and agnostic ideas would therefore represent the civil interests and cultural instances of that part of society that does not identify with any religion and that would forcefully oppose the complex theocratic system, which is still far from an affirmation, especially in societies where the extraordinary conversions today involve the human condition, all the cultures of the world and revolve around two basic factors that give rise to these metamorphoses: globalization and the development of new technologies.

One can understand why in that philosophical-religious game, the Americans have "secularly" positioned themselves, actively engaging in the control of activities in the nuclear sector, while the Europeans, both "East, and West", have often engaged in trying to enforce human rights and freedom of expression, as if these were the issues on which to focus their strategies. Both have been unwilling to address the central issue, the existential one of an eschatological model, which has always influenced Iranian politics, and which even today, remains to be defined.

Let us not forget that Iran is having to deal with a rearrangement of regional balances following the wave of popular protests and in the face of a delicate international situation in the Syrian conflict. Iran continues to alternate its two faces, that of empty rhetoric and a second more pragmatic one. Who knows until when it will remain halfway between tradition and future, poised between conservatives and progressives. Today the Islamic Republic remains a place of great social and cultural

\footnotetext{
${ }^{53}$ Cf. E. Morin, Dove va il mondo? preface by François L'Yvonnet, Armando, Rome, 2012.
} 
ferment that is trying to secure political prestige, I am convinced that Iran has the potential to establish itself as a force for regional stability and not disorder. Yet Iran's history must also be judged over the long term.

There are facts, equally new, that presage a change, a projection into the future, that indicates a new way forward. Whichever way the negotiations on the nuclear issue go, the road is long and must necessarily pass through diplomatic agreements and a path of consolidation, a delicate and risky game on which the destiny of the Middle East will depend, with many players on the scene, including the Zionist lobby. The confrontation must be possible, there is no alternative.

With Ahmadinejad's exit from the scene, ends a difficult era for Iran, linked to international tensions arising from the nuclear issue, the problematic relationship with the United States, the events of 2009 that led to an internal crisis, including the complex relations with Khamenei and the Parliament. All this had indeed contributed to fragmenting the already confused and conflicting internal panorama. The election of Rouhani (2017) has suddenly, and paradoxically, brought Western countries and Ali Khamenei, whose opinions rarely converge, into an agreement. Rouhani is exactly a figure fully internal to the Islamic revolution, and at the moment the theocratic summit probably continues to consider him a reliable figure, who does not want or cannot give the radical turn that many hope for.

The changes realistically foreseeable today are minimal, even if sometimes the historical crises escape the control of the transitional figures, or the same transitional figures behave unexpectedly. At stake is the theocratic model that was even the reason for the attraction of the Arab Springs ${ }^{54}$.

Today is the time for a change, even if in a country like Iran, everything is moving slowly. Young Iranians will have to obtain a role, reorganize and rekindle themselves from below. The involvement of young people themselves can increase hope in a process that is going to be complex and articulated, that sees the theocratic model as opposed to the Muslim political model in an eschatological context that to Westerners appears anachronistic, where there is no discussion on eschatological bases but only, alas "venally" and trivially economic, in a fall of values and feelings without equal that in a few decades will be able to change the political, social, economic, cultural and environmental perspective of Iran, transforming its daily life and interpersonal relations.

Certainly, the elections in Iran took place last June 18 saw the victory of the most accredited candidate, the conservative Raisi, head of the judiciary and a figure considered close to the Supreme Leader Khamenei.

Poor, both in candidates and votes, the reformist area, which is about to undergo a phase of complete restructuring. Everything will be played out on the economic front, it is not enough to criticize the management of Rouhani, there is a need to make the Iranian economy autonomous and independent. A sort of economicfinancial autarchy, which would utopically allow the country to be less exposed to the pressures caused by international sanctions. We'll see...

\footnotetext{
${ }^{54}$ A. Figus, Iran's foreign policy between the West and the nuclear crisis, Eurilink, Rome, 2014.
} 


\section{References}

Abdolmohammadi, P., "Il repubblicanesimo islamico dell'Ayatollah Khomeini”, Oriente Moderno, Nuova serie, Anno 89, Nr. 1, 2009.

Bausani, A., L’Islam, Garzanti, Milano, 1987.

Bausani, A., L'Islam, op. cit. e P. Branca P., Introdurione all'Islam, Edizioni San Paolo, Milano 1995.

De Martino, E., Il mondo magico. Prolegomeni a una storia del magismo (1948), Boringhieri, Torino 1997.

De Martino, E., La fine del mondo. Contributo alle analisi delle apocalissi culturali (1977), Einaudi, Torino 2002.

Figus, A., Politica estera dell'Iran tra Occidente e crisi nucleare, Eurilink, Roma 2014.

Guolo, R.,, Il fondamentalismo islamico, Laterza, Bari 2002.

Khomeyni, R., Il Governo Islamico, LedE, Roma 1980.

Morin. E. Dove va il mondo?, prefazione di François L'Yvonnet, Armando, Roma 2012

Ozzano, L., Fondamentalismo e democrazia, Il Mulino, Bologna 2009

Saffari, S., "The Legitimation of the Clergy's Rights to Rule in the Iranian Constitution of 1979", British Journal of Middle Eastern Studies, Vol. 20, no. 1, 1993. 